\title{
Some Aspects of the Clinical Anatomy of the Mandibular and Maxillofacial Regions of the West African Dwarf Goat in Nigeria
}

\author{
Aspectos de Anatomía Clínica de las Regiones Mandibular y Maxilofacial \\ de la Cabra Enana del Oeste Africano en Nigeria \\ Olopade, James Olukayode \& Onwuka, Silas Kalu
}

OLOPADE, J. O. \& ONWUKA, S. K. Some aspects of the clinical anatomy of the mandibular and maxillofacial regions of the west african dwarf goat in Nigeria. Int. J. Morphol., 23(1):33-36, 2005.

SUMMARY: Some measurements in the mandibles and upper jaws of thirty West African Dwarf (WAD) goats without any apparent skeletal disorders were analysed. The length and height of the mandibles were $12.00 \mathrm{~cm}$ and $6.90 \mathrm{~cm}$, respectively. The distance from the lateral alveolar root to the mental foramen, from the mental foramen to the caudal mandibular border were $1.56 \mathrm{~cm}, 9.96 \mathrm{~cm}$, and $2.58 \mathrm{~cm}$ respectively. The width and height of the mental foramen were $0.5 \mathrm{~cm}$ and $0.3 \mathrm{~cm}$, respectively. These data are discussed with regard to their application to clinical manoeuvres around the head of the goat such as regional anesthesia during dental extraction.

KEY WORDS: Clinical Anatomy; Skull; Goat.

\section{INTRODUCTION}

Regional anatomy is an important branch of anatomy directly concerned with the form and relationships of all the organs present in a particular area. Regional anatomy is one of the foundations of clinical and surgical practice because it enables the clinical/surgeon to visualize details of structures relevant to the case at hand (Dyce et al., 1996).

The regional anatomy of the head is very important because of such vital organs and structures as the brain, tongue, eyes as well as ears, teeth, nose, lips, horn and skull. The head is thus needed for coordinating the body as well as for deglutition, olfaction and defence (Dyce et al.; Olopade, 2003). The foramina in the skull are of clinical importance in regional anaesthesia around the head (Hall et al., 2000).

Some previous work had been done on the heads of domestic animals including the horse, ox and dog (Getty, 1975; Dyce et al.; Onar et al., 2001). However, apart form a preliminary report on the brain morphometry (Onwuka et al., 2003), dental eruption and oral pathologies (Otesile \& Obasaju, 1982; Kene \& Agbo, 1998) there is very little information on the regional anatomy of the head of WAD goats.

This study was designed to provide information on some clinically important parameters in the lower and upper jaw bones of the WAD goat.

\section{MATERIAL AND METHOD}

Animals: In this study, a total of 30 skulls of WAD goats were used. The live animals were first selected during antimortem examination at an abattoir based on parameters of apparent good health and no skeletal deformation. When the goats were slaughtered, their heads were severed at the occipitoatlantal joint and processed according to the hot water maceration techniques to Tasbas \& Tecirlioglu (1996) and the University of Arizona cooperative and extension paper on cleaning and skull preparation (1999) which briefly were:

1. Frozen goat head were allowed to thaw.

2. Eyes were enucleated and most of the skin and muscles separated.

3. Heads were put in solution of polycaboxylate and anionic surfactant(detergent) and soap chips and heated to over $80^{\circ} \mathrm{C}$ for at least 30 minutes.

4. Boiled heads were put in running water and muscle separated with the aid of knives.

5. The skulls were left in detergent water for at least 20-30 minutes.

6. Further separation of muscles and ligament was done.

7. The skulls were left I n $1 \%$ sodium hypochlorite solution. for at least 24 hours and separation of remaining muscles and ligaments was done.

8. The skulls were left in the above solution, for 48-72 hours with solution, being changed at least twice.

9. The skulls were then left to dry. 
The measurements on the upper jaw and mandibles were done with metric rules and the results were presented as means \pm S.D.
Measurements. Parameters measured in the upper and lower jawbones of the WAD skulls include (Figs 1,2,3).

\begin{tabular}{|c|c|}
\hline A & $\begin{array}{l}\text { Facial tuberosity to infra-orbital canal: From the level of the most lateral bulging of the facial tuberosity to both } \\
\text { extremities of infra-orbital canal. }\end{array}$ \\
\hline B & $\begin{array}{l}\text { Infra-orbital canal to root of alveolar tooth: Measurement is from the level of ventral and dorsal ends of the in infra- } \\
\text { orbital canal. }\end{array}$ \\
\hline $\mathrm{C}$ & $\begin{array}{l}\text { Mandibular length: From the level of the cranial extremity of the alveolar root of the lower incisors to the level of the } \\
\text { caudal border of the mandible. }\end{array}$ \\
\hline $\mathrm{D}$ & $\begin{array}{l}\text { Lateral alveolar root to mental foramen: Shortest distance from the mental foramen to the lateral extent of the alveolar } \\
\text { root of lower incisor. }\end{array}$ \\
\hline $\mathrm{E}$ & $\begin{array}{l}\text { Mental foramen to the caudal mandibular border: From the level of the mental foramen to the extreme caudal border of } \\
\text { the mandible. }\end{array}$ \\
\hline $\mathrm{F}$ & $\begin{array}{l}\text { Mandibular foramen to base of mandible: Vertical line form the ventral limit of the mandibular foramen to the base of } \\
\text { the mandible. }\end{array}$ \\
\hline G & Caudal border of mandible to the vertical line produced by the description F above. \\
\hline $\mathrm{H}$ & Maximum height of the mandible to the condyloid fossa. \\
\hline I & Width/height of the mental foramen. \\
\hline $\mathrm{J}$ & Condyloid fossa to the base of the mandible \\
\hline $\mathrm{K}$ & Maximum mandibular height: From the basal level of the mandible to the highest level of the coronoid process. \\
\hline
\end{tabular}

Fig. 1. Skulls of WAD Goat. Lateral view.

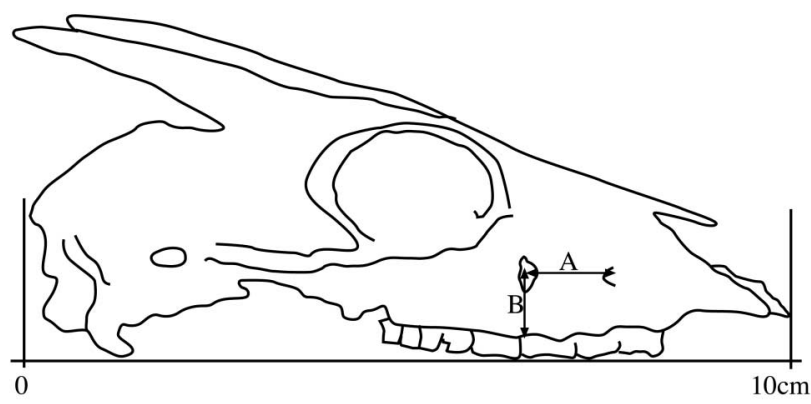

A: Facial tuberousity to infraorbital canal

B: Infraorbital canal to root of alveolar tooth

Fig. 3. Mandible of WAD Goat. Median view.

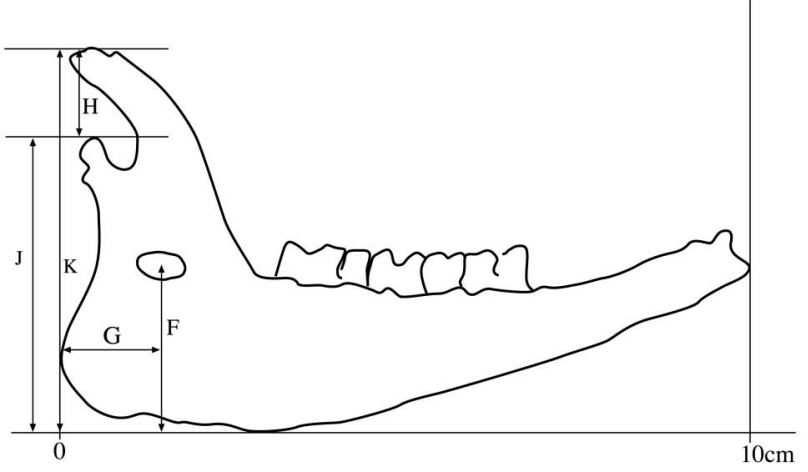

F: Mandibular foramen to base of mandible

$\mathrm{G}$ : Caudal line of mandible to condyloid fosse

$\mathrm{H}$ : Maximum height to condyloid fosse

$\mathrm{K}$ : Maximum height of mandible
Fig. 2. Mandible of WAD Goat. Lateral view.

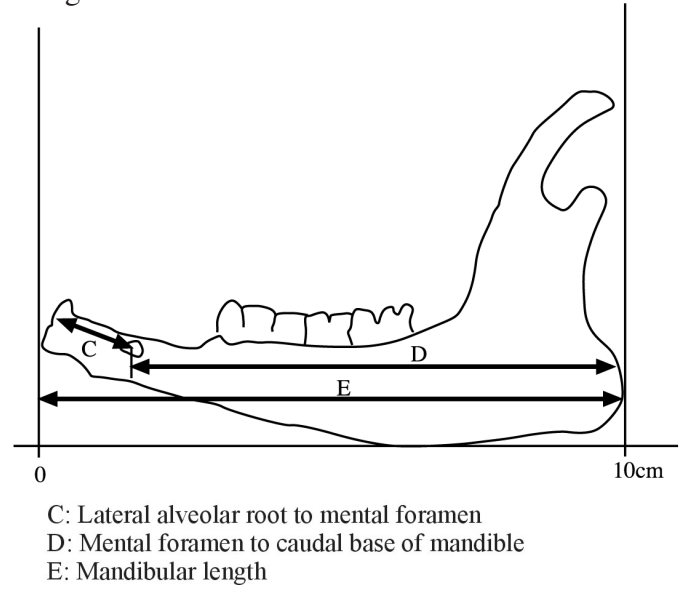

RESULTS AND DISCUSSION

Table I. The measurements of the upper jaw and mandible of WAD goats. (Description is based on the alphabetical order outlined in materials and methods).

\begin{tabular}{lcc} 
& Mean value $(\mathrm{cm})$ & S.D. \\
\hline $\mathrm{A}^{*}$ & $1.6-1.8$ & - \\
$\mathrm{B}^{*}$ & $1.3-1.6$ & - \\
$\mathrm{C}$ & 12.00 & 1.89 \\
$\mathrm{D}$ & 1.56 & 0.22 \\
$\mathrm{E}$ & 9.96 & 1.67 \\
$\mathrm{~F}$ & 2.58 & 0.34 \\
$\mathrm{G}$ & 1.57 & 0.44 \\
$\mathrm{H}$ & 2.21 & 0.37 \\
$\mathrm{I}$ & $0.5-0.3$ & - \\
$\mathrm{J}$ & 2.68 & 0.45 \\
$\mathrm{~K}$ & 6.90 & 1.09
\end{tabular}


The mandible of WAD goat was found to have a length of $12.00 \pm 1.89 \mathrm{~cm}$ and height of $6.90 \pm 1.09 \mathrm{~cm}$. The caudal border of the mandible to the vertical line downwards form the middle of the mandibular foramen (Fig. 3) was $1.57 \pm 0.44$ $\mathrm{cm}$, while the distance from the mandibular foramen to the base of the mandible was $2.58 \pm 0.34 \mathrm{~cm}$. These parameters are of clinical importance as a guide for mandibular nerve block necessary for clinical examination and operations on the alveoli and teeth of the lower jaw. Equivalent figures for the horse and dogs were $3 \mathrm{~cm}$ and 1.5 to $2 \mathrm{~cm}$ respectively for the distance between the mandible foramen and base of the mandible (Hall et al.). The mental nerve block is indicated in the suturing of the lower lips and for operations on the lower incisors and first 1-2 premolars. The data obtained here of $1.56 \pm 0.22 \mathrm{~cm}$ for the distance between the lateral end of the alveolus of the incisor tooth to the mental foramen and $0.5-0.3 \mathrm{~cm}$ for the width and height on the foramen will serve as a guide in the location of the mental nerve for this regional nerve block.

The distance from the facial tuberosity to the infraorbital canal and from the latter to the root of the alveolar tooth directly ventral to it were in the range of $1.6 \mathrm{~cm}-1.8$ $\mathrm{cm}$ and 1.3-1.6 $\mathrm{cm}$ respectively. The data is of clinical importance because the facial tuberosity is very prominent even in live animals as a guide to tracking the infraorbital nerve, and the data obtained in this study will greatly facilitate precise tracking of the nerve, the desensitisation of which affects the skin of the lip, nostril and face on that side of the level of the foramen. The injection of local anesthetic agents within the canal via the infra-orbital foramen will also lead to analgesia of the incisor, canine and first two premolars. The infra-orbital canal in the horse has been estimated to be $4-5 \mathrm{~cm}$ along a line passing forward and downward from the anterior end of the facial crest (Hall et al.). Goats have no facial crest but in the WAD goat, the infra-orbital foramen was located directly dorsal to the second or junction of the first and second upper premolar. This information coupled with the observed distance of $1.3 \mathrm{~cm}-1.6 \mathrm{~cm}$ between the root of the teeth and the foramen would prove a vital guide to regional anesthesia involving the infra-orbital nerve in the WAD goat.

As earlier stated, there is no previous information on these parameters in WAD goats, nor in any other domestic animals in Nigeria with which comparisons could be made. We therefore believe that the data presented above will form a vital baseline for further work especially comparability and compatibility are now desirable traits as efforts are geared up towards massive improvement in the livestock sector of the international economy.

OLOPADE, J. O. \& ONWUKA, S. K. Aspectos de anatomía clínica de las regiones mandibular y maxilofacial de la cabra enana del oeste africano en Nigeria. Int. J. Morphol., 23(1):33-36, 2005.

RESUMEN: Fueron analizadas algunas medidas en la mandíbula y maxila de treinta cabras enanas, del Oeste de Africa (WAD) sin desórdenes esqueléticos aparentes. La longitud y altura de la mandíbula fueron $12,0 \mathrm{~cm}$ y $6,9 \mathrm{~cm}$, respectivamente. Las distancias desde la raiz alveolar lateral al foramen mental y desde este último al margen inferior de la mandíbula, fueron 1,56 cm y $2,58 \mathrm{~cm}$, respectivamente. El ancho y altura del foramen mental fueron $0,5 \mathrm{~cm}$ y $0,3 \mathrm{~cm}$, respectivamente. Estos datos son discutidos considerando las maniobras de aplicación clínica realizadas en la cabeza de la cabra, como también con los procedimientos de anestesia regional durante la extracción dental.

PAlABRAS ClAVE: Anatomía clínica; Cráneo; Cabra.

\section{REFERENCES}

Dyce, K. M; Sack, W. O \& Wensing, C. J. G. Textbook of Veterinary Anatomy. 2. ed. Philadelphia, Saunders, 1996.

Getty, R. Ruminant Myology in: The Anatomy of the Domestic Animals. 5. ed. Philadelphia, Saunders, 1975. V. 2.

Hall, L. W; Clarke, K.W \& Trim, C.M. Wright's Veterinary Anaesthesia and Analgesia. 10. ed. London, ELBS and Baillierre Tindall, 2000.

Kene, R. O. C \& Agbo, C. N. Dental abnormalities of three breeds of Nigerian goat. Tropical Veterinarian, 16:1522,1998 .
Olopade, J. O. The Morphometry of the craniofacial and maxillofacial regions of the West African Dwarf Goats (Capra hircus). M. Sc. thesis, Department of Veterinary Anatomy, University of Ibadan, Ibadan, Nigeria, 2003.

Onar, V; Ozcan, S \& Pazvant G. Skull Typology of Adult male kangal dog. Anat. Histol. Embryol., 30:41-8, 2001.

Onwuka, S. K; Olopade, J. O.; Babajide, B. F. \& Ehimiyien IO. Preliminary morphometric investigation of the brain of West African Dwarf Goat. Procceedings of the 39th Annual Conference of the Nigerian Veterinary Medical Association held in Sokoto, Nigeria. Pp 57-9, 2003. 
Otesile, E. B. \& Obasaju, M. F. Relationship between age rostral teeth development in Nigerian goats. In proceedings of the $3 \mathrm{rd}$ international conference on Goat Production and Disease University of Arizona. Tucson, Arisona. U.S.A, Jan. 1982.

Tasbas, M \& Tecirlioglu S. Meserasyon teknigi uzerinde arasirmalar. Ank. Uni. Vet. Fak. Derg. Xll, 4:324-30, 1996.

University of Arizona. The University of Arizona cooperative extension consultancy paper on cleaning and preserving animal skulls. Sullivan, M. L. and Park Romney, C (authors). ag. Arizona.edu/pubs/inatresources/ az1144.pdf1999.
Correspondence to: Prof. Dr. James Olukayode Olopade Department of Veterinary Anatomy Faculty of Veterinary Medicine University of Ibadan

Ibadan

$\mathcal{N I G E R I A ~}$

Phone:+234-8023860829

E-mail:jkayodeolopade@yahoo.com

Received: 08-10-2004

Accepted: 21-12-2004 